\title{
New mosses of North America. V.
}

\author{
F. RENAULD AND J. CARDOT.
}

WITH PLATES XXI AND XXII.

Archidium Hallii Aust. var. minus.-Smaller than the type, from which it differs besides in the leaves shorter and the costa percurrent or shortly excurrent.

Louisiana: near Mandeville (A. B. Langlois, I892).

Dicranella leptotrichoides. - Resembling in habit Leptotrichum tortile. Dioecious, small, loosely cespitose, green. Stems short, erect, simple, $2-5^{\mathrm{mm}}$ long. Leaves erect or subsecund, lanceolate, acuminate, subacute or rather obtuse at the apex, quite entire, borders plane or partly revolute; costa stout, percurrent; cells of the areolation oblong or sublinear, shorter looser and subrectangular below. Perichaetial bracts scarcely different, a little longer. Pedicel $5-7^{\mathrm{mm}}$ long, yellowish when young, afterwards reddish. Capsule small, erect, symmetric, ovate-oblong, scarcely constricted under the orifice when dry; lid equalling the sporangium, long and obliquely subulate-rostrate. Peristome purple, teeth trabeculate, striolate lengthwise, cleft to below the middle into 2-3 subulate legs, granulose and partly connected; annulus very broad, deciduous, of $2-3$ rows of cells. Male plant unknown.

Louisiana: on slopes, Rivière Tchiffouté, Abita Springs, Covington, Fontainebleau near Mandeville $(A$. B. Langlois, I89I-I892). We have also specimens collected near Mobile, Alabama, by Sullivant, and distributed as Trichostomum
tenue.

Closely allied to D. Tonduzii Ren. et Card. from Costa Rica; but distinguished by the leaves straight when dry and the areolation different.

Fissidens falcatulus.-Very small, gregarious, yellowish green. Stems rather rigid, plumulose, $2-4^{\mathrm{mm}}$ long. Leaves 4-8 pairs, falcate-secund and rigid when dry, linear-lancelength acute or subapiculate; vaginant lamina about one-half ing below, apical bordered, dorsal lamina not bordered, tapernutely crenulateal lamina without a border, subentire or milation pellate at the apex; costa pale, subpercurrent; areo- 
Louisiana: on bark of trees, Catahoulou, near Mandeville and bayou Alexandre (A. B. Langlois, I890-I89I).

Very near to $F$. exiguus Sulliv., from which it is distinguishable by the rigid habit, the leaves narrower and falcate-secund when dry, and the more pellucid areolation.

Physcomitrium turbinatum Brid. var. erassipes. (P. Hookeri var. serratum Ren. et Card. Musc. Am. sept., p. 3I).-Pedicel short $\left(4-6^{\mathrm{mm}}\right)$, thick; capsule deoperculate, cup-shaped.

Oregon (herb. Lesquereux): Sandy $\operatorname{river}(L$. F. Henderson), Willamette river (Th. Howell).

Bryum bimum Schreb. var. atrotheca.-Capsule black-red; leaves scarcely denticulate or quite entire at the point.

Newfoundland (Rev. A. C. Waghorne, I892).

Timmia Austriaca Hedw. var. brevifolia.-Differing from the typical form by the stems shorter and the leaves more crowded, shorter and erect-imbricate, scarcely flexuous when dry.

Colorado: Springdale, Boulder Co. (Marie Holzinger, 1892. Comm. J. M. Holzinger).

Pylaisia polyantha Sch. var. Coloradensis.-Distinct from the type in the green tint and the cells shorter, very chlorophyllose.

Colorado: Springdale, Boulder co. (Marie Holzinger, 1892, Comm. J. M. Holzinger).

Brachythecium salebrosum Sch. var. Waghornei.-A peculiar form, distinguishable from the type by the tufts very dense, the stems erect, turgid, not radiculose, the leaves more crowded, imbricate, and the lid mamillate. Differs from the allied $B$. mamilligerum $\mathrm{Kindb}$. in the leaves imbricate, not patulous when dry, and the stems not radiculose. Much smaller than B. turgidum Hartm.-Monœcious!

Labrador: Battle Harbor (Rev. A. C. Waghorne, 1891. Comm. Rev. C. H. Demetrio).

Brachythecium suberythrorrhizon.--Monœcious, intricatecespitose, yellowish-green, facies of B. velutinum. Stems creeping, radicose, sparingly branching, branches procumbent. Leaves subhomomallous, oblong-lanceolate, long narrowly acuminate, bi-tri-plicate, sharply serrate all around; borders plane or partly revolute, costa vanishing above the middle, sometimes forked and shorter; areolation rather loose, pellucid, cells rhomboidal-linear, the alar quadrate, sub-obscure. Perichaetial bracts lanceolate, long acuminate-subulate, acumen serrate. Pedicel smooth, reddish, IO $-12^{\mathrm{mm}}$ long. Capsule suberect, turgid-ovate, not or scarcely constricted 
below the mouth when dry; lid unknown. Teeth of the peristome yellowish, triangular-lanceolate, segments narrow, split along the divisural line, cilia I or 2 , long, filiform.

Colorado: Springdale, Boulder co. (Marie Holzinger, 1892. Comm. J. M. Holzinger).

Nearly allied to B. erythrorrhizon Sch., from which it differs in the narrower leaves and the looser areolation.

Brachythecium reflexum Sch. var. Demetrii.-Differs from the genuine form in the stronger habit, the thicker erect branches, and the broader softer leaves.

Labrador: Squaw Island (Rev. A. C. Waghorne, I891. Comm. Rev. C. H. Demetrio).

Eurhynchium Sullivantii L. et J. var. Holzingeri.-Differs from the type in the branches shorter, generally obtuse, and the leaves broader and shorter acuminate.

District of Columbia: near Washington (F. V. Coville, r889-1890. Comm. J. M. Holzinger).

Thamnium Holzingeri.-Green, slender, rather resembling in habit the small forms of Isothecium myosuroides. Primary stems creeping, stoloniform, secondary ascending or decumbent, more or less shrub-like, pinnate, branches complanate, generally attenuate. Lower stem leaves small, erect-spreading, from a broadly deltoid base ligulate-obtuse; costa vanishing about the base of the acumen; upper leaves larger, distichous, complanate, slightly asymmetric at the base, oblong-ligulate, obtuse or subobtuse, costa vanishing far from the apex, sometimes forking above; branch leaves smaller, with the costa shorter and the lower margin inflexed, the upper leaves acute; all the leaves plane and crenulateserrate on the margins, coarsely and irregularly dentate at the apex; areolation parenchymatous, cells incrassate, short, chlorophyllose, roundish or subhexagonal above, ovate or
oblong in the middle, sublinear below, the alar small, rather
obscure, obscure, subquadrate or roundish. Inner perichaetial bracts subvaginant, oblong-lanceolate, long loriform-acuminate, serrulate, costa thin, cells narrower; vaginule covered with numerCapsul long paraphyses. Pedicel smooth, reddish, short $\left(6-9^{\mathrm{mm}}\right)$. orifice when , oblong, subsymmetric, constricted under the peristome dry, lid conic, obliquely beaked. Teeth of the mentsme yellowish, lanceolate-acuminate, subulate, segnodose. narrowly split along the divisural line, cilia 2, long, Oregon: Seems to be diœcious. 1892. Mon: Myrtle Point, Coos co. (Rev. G. A. Holzinger, 
This fine little moss cannot be confounded with any other North American or European species. It rather resembles some small tropical species of the genus Homalia and Porotrichum, but is easily distinguished from these by the perfect peristome, with long cilia.

Amblystegium Holzingeri.-Loose, green or yellowish green. Stems depressed, irregularly branching. Leaves very loose, distant, patulous, ovate-lanceolate, broadly and obtusely acuminate, quite entire; costa generally simple, thin, vanishing above the middle, sometimes forked and shorter. Areolation rather loose, cells oblong or linear, flexuous, with the primordial utricle distinct, the alar shorter, looser. Perichaetial bracts oblong-lanceolate, acuminate, very entire, costate, more narrowly reticulate. Pedicel short, $6-8^{\mathrm{mm}}$ long, reddish. Capsule inclined or subhorizontal, small, ovate, arcuate, much constricted below the mouth when dry, lip depressed, obtusely apiculate.

Virginia: bank of Potomac. District of Columbia: Rock Creek. (F. M. Holzinger, I891-1892.)

Allied to $A$. adnatum, but easily distinguished by the shortacuminate and obtuse leaves, the generally simple costa, the looser and less numerous alar cells, the shorter capsule and the more depressed lid.

Hypnum giganteum Sch. var. Labradorense.-A notable variety, distinct from the type by the leaves larger and longer and the costa attenuate, vanishing rather far from the apex and often forking.

Labrador: Battle Harbor (Rev. A. C. Waghorne, 1892).

Vesoul and Stenay, France.

Explanation of Plates XXI and XXII.

All the figures magnified are drawn by means of Nachet's camera lucida.

Plate XXI.-A. Dicranella leptotrichoides. $a$, entire plant; $b, b$, leaves; $c$, areolation of the basal borders of the same; $d$, do. in the middle; $e$, capsule with the lid; $f$, capsule deoperculate; $g$, portion of the annulus; $h$, two teeth of the peristome.-B. Fissidens falcatulus, $a$, entire plant; $b$, upper part of a stem; $c, c$, leaves; $d$, apex of a leaf; $e$, areolation of the margin of the vaginant lamina.-C. Amblystegium Holzingeri. $a$. entire plant; $b, b, b, b$, leaves; $c$, alar cells; $d$, areolation in the middle; $e, e$, areolation of the apex; $f$, capsule operculate; $g$, the same deoperculate. PLATE XXII.-A. Thamnium Holzingeri. $a$, entire plant; $b$, portion of a
branch; $c, c$, lower stem leaves: $d$. Theres; . branch; $c, c$, lower stem leaves; $d, d$, upper stem leaves; $e$, branch leav the margin, in the middle; $j$, areolation of the apex; $k$, inner perichaetial bract; $b$, capsule with the lid; $m$, portion of the peristome.-B. Brachythecitum the
erythrorrhizon. $a$, entire plant; $b, b, b$, leaves; $c$, alar cells: $d, d$, point of the same; $e$, capsule deoperculate; $f$, leaf of $B$. erythrorrhizon Sch. 


\section{$2 \mathrm{BHL}$ Biodiversity Heritage Library}

Renauld, Ferdinand and Cardot, Jules. 1894. "New Mosses of North America. V." Botanical gazette 19(6), 237-240. https://doi.org/10.1086/327053.

View This Item Online: https://www.biodiversitylibrary.org/item/93164

DOI: https://doi.org/10.1086/327053

Permalink: https://www.biodiversitylibrary.org/partpdf/222370

\section{Holding Institution}

Missouri Botanical Garden, Peter H. Raven Library

\section{Sponsored by}

Missouri Botanical Garden

\section{Copyright \& Reuse}

Copyright Status: Public domain. The BHL considers that this work is no longer under copyright protection.

This document was created from content at the Biodiversity Heritage Library, the world's largest open access digital library for biodiversity literature and archives. Visit BHL at https://www.biodiversitylibrary.org. 